\title{
Rhetorical, Political, and Ecclesiastical Perspectives of Augustine's and Julian of Eclanum's Theological Response in the Pelagian Controversy
}

\author{
Nozomu Yamada \\ Nanzan University (Nagoya, Japan) \\ nozomu@nanzan-u.ac.jp
}

\begin{abstract}
In Opus imperfectum, Augustine's last controversy against Julian of Eclanum, we can recognize these two theologians' rhetorical devices in which they tried to condemn each other as heretics. Particularly in the interpretations of both polemists on the issue of human sexual desire, Augustine and Julian fiercely confronted each other, making extensive use of a variety of rhetorical measures. In this article, referring to important recent research while at the same time focusing on crucial primary texts, I first would like to clarify these rhetorical arguments, particularly, the supremacy of Augustine in using such rhetorical devices. Next, the quite different philosophical frameworks of both polemists are clarified. In addition, the political and ecclesiastical perspectives of Augustine's and Julian of Eclanum's theological reasoning are investigated and the political tactics and ecclesiastical diplomacy of Augustine clarified. The ultimate purpose of this article is to explicate the mechanism and the true reasons for the victory of Augustine and the excommunication of Julian and other Pelagians.
\end{abstract}

\section{Keywords}

Augustine - Julian of Eclanum - rhetolic - sexual desire - political tactics

* This study was supported by JSPS (Japan Society for the Promotion of Science) 'Kakenhi (Grant-in-Aid for Scientific Research (C) (2017); research number 15K02088)' and also by a Nanzan University Pache Research Subsidy I-A-2 (2018 academic year). 
Julian of Eclanum, one of the disciples of Pelagius, tormented Augustine greatly in his later years about his dogmatic evaluations of the freedom of the will, sexual desire, and original sin, among other things. Augustine's victory in the serious controversy with Julian made it possible for Augustine's doctrine of original sin to become the centre of western theological traditions. No one denies that Augustine's doctrine of original sin had enormous influence among subsequent western theology. Nevertheless, if we survey the history of Christian theologies from a wider perspective, we can recognize the significant fact that neither Augustine's doctrine of original sin nor his theory of predestination have left any traces in the traditions of the eastern churches. This historical fact should make us reconsider Augustine's final controversy with Julian and also make us reexamine the legitimacy of Augustine's doctrine of original sin, particularly his interpretation of human sexual desire.

On the other hand, research about Pelagius and his disciples, particularly Julian of Eclanum, has made remarkable progress over these past 40 years. In this article, based on recent studies that reevaluate the writings of the Pelagians, I would like to clarify that there were not heretical but very correct arguments underlying Pelagius' and Julian's assertions, particularly by pointing out their rhetorical tactics, which Augustine used freely in his controversial works against the Pelagians. That is, the main purposes of this article, from the viewpoint of defending the legitimacy of the Pelagians, are firstly to clarify the rhetorical tactics used by Augustine in order to determine that Pelagians were heretical; secondly, to describe the political biases of and influences on theological statements by Augustine and Julian; thirdly, to point out crucial ecclesiastical and political situations, in which Pelagians, Augustine, and also the bishop of Rome were located; and finally, to provide, from a bird's-eye point of view from micro-level theological disputes up to much wider macro-level church-historical tensions, the principal reasons why Augustine won and the Pelagians lost these fierce controversies. To facilitate this exploration I have adopted an ideology-critical hermeneutic approach.

\subsection{Prior Research on Pelagians}

One of the most important and detailed recent explanations of the Pelagians is the 2002 paper of M. Lamberigts. ${ }^{1}$ This paper generated a stream of Pelagian

1 M. Lamberigts, "Recent Research into Pelagianism with Particular Emphasis on the role of Julian of Aeclanum," Augustiniana, $5^{2}$ (2002) pp. 175-198. 
studies that evaluated Pelagians no longer as a heretical sect but rather as successors of an authentic Christianity.

Even though A. Souter's excellent work reconstructing Pelagius' Pauline commentary was published about 100 years ago, ${ }^{2}$ there were only ten or so studies that focused specifically on the works of Pelagius and Pelagians and described their originality and commendability. It was in only in 1956 that J. Ferguson offered his study dealing with Pelagius individually ${ }^{3}$ and the next year that T. Bohlin explored the origin of Pelagian works pointing out, for the first time, their direct relationships with eastern theology. ${ }^{4}$ Although until the end of the third quarter of the last century the main stream of Pelagian studies, generally considered part of Augustine studies, provided negative evaluations of Pelagius as a "moralist," "stoic optimist," or obvious "heretic," in 1972 G. Greshake published the epoch-making study of Pelagius' theology, Gnade als konkrete Freiheit. Eine Untersuchung zur Gnadenlehre des Pelagius. ${ }^{5}$ This study skillfully described the intense relationship of Pelagius' thought with eastern orthodox theology and anthropology, not as historical, philological research but rather as a comparative study in dogmatic structural resemblance between Pelagius and eastern church fathers. Under the influence of Greshake's research, G. Garcia-Sanches' Pelagius and Christian Initiation: A Study in Historical Theology 6 and S. Thier's ecclesiastical research were published.7 In 2001, J. Lössl's monumental study on Julian of Eclanum, Julian von Aeclanum. Studien zu seinem Leben, seinem Werk, seiner Lehre und ihrer Überlieferung was released, ${ }^{8}$ which explored Julian as a peculiar research-object, represented a new stage of Julian research. In 1997, N. Yamada, a Japanese scholar of Pelagius (and author of this present article), published his disserta-

2 A. Souter, Pelagius's Expositions of Thirteen Epistles of St. Paul, ed. by J.A. Robinson, Cambridge, 1922-1931.

3 J. Ferguson, Pelagius: A Historical and Theological Study, Cambridge, 1956.

4 T. Bohlin, Die Theologie des Pelagius und ihre Genesis, Uppsala -Wiesbaden, 1957.

5 G. Greshake, Gnade als konkrete Freiheit. Eine Untersuchung zur Gnadenlehre des Pelagius, Mainz, 1972.

6 G. Garcia-Sanches, Pelagius and Christian Initiation: A Study in Historical Theology, Ann Arbor, Mich., 1979.

7 S. Their, Kirche bei Pelagius, Berlin-New York, 1999.

8 J. Lössl, Julian von Aeclanum. Studien zu seinem Leben, seinem Werk, seiner Lehre und ihrer Überlieferun, Leiden-Boston, Köln, 2001. Lössl's article "Augustine, 'Pelagianism', Julian of Aeclanum and Modern Scholarship," ZAC, 11 (2017), pp. 129-150, is very significant and noteworthy particularly with regard to the need for more socio-cultural and political approaches in modern Augustinian and Pelagian studies. Lössl's introduction of the studies of E. Clark, J.M. Salamito, and W. Wischmeyer is useful. 
tion in Japan, Example of Christ:Justice of God and Paideia of Pelagian Theology, which made clear, from an affirmative view for Pelagius, the direct and indirect influences on Pelagius' theological understanding of the justice of God and the dynamic function of exemplum Christi from the eastern traditions. ${ }^{9}$ Unfortunately, this study has not been referred to outside Japan as it was written in Japanese.

Nevertheless, despite such new streams of Pelagian studies, the main stream of Augustinian studies by Augustine researchers continued to provide conservative evaluations of Pelagians. G. Bonner, for example, wrote even in the third edition of Augustine's biography, St. Augustine of Hippo, about the Pelagians, "In any case, the attitude to religion of Pelagians like Caelestius and Julian of Eclanum seems to have been essentially moral and intellectual. They had little sense of mystery ...."10 Also, B.R. Rees' Pelagius: A Reluctant Heretic, could not get away from Pelagius' heretical image, although Rees' English translations of the Pelagian corpus were highly evaluated because of their availability.11

In such conservative academic streams around Pelagian-Augustinian studies, one noteworthy book was published in 1978 in Italy, Tradux Peccati, by P.F. Beatrice. ${ }^{12}$ This study investigated the basis of Augustine's doctrine of original sin through multiple materials. Beatrice pointed out the possibility of Jewish Christian Encratism, that is, that the origin of Augustine's doctrine of original sin was the notion of hereditary sin of the Encratites, the Messalians' teaching carried by Jewish Christian communities. ${ }^{13}$ On the other hand, Beatrice noted that almost all of the eastern Greek fathers objected to this theological stream of encratite hereditary sin, and Pelagius' and Julian's anti-Augustinian assertions were the very same theological attitude as those of the eastern church fathers. ${ }^{14}$ Unfortunately, although this study was distinguished in Augustine studies, it did not so attract much attention at the time, because the book was initially published in Italian. More recently, however, since the English translation of this study was published in $2013,{ }^{15}$ Beatrice's book has gradually been

N. Yamada, Example of Christ: Justice of God and Paideia of Pelagian Theology, Tokyo, 1977 (Japanese original title of this book, Kirisuto no Mohan, Pelagius shingaku niokeru Kaminogi to Paideia, Tokyo, 1997).

10 G. Bonner, St. Augustine of Hippo, Norwich, 2002, 3rd edn, p. 365.

$11 \quad$ B.R, Rees, Pelagius: A Reluctant Heretic, Woodbridge, 1988; B.R. Rees, The Letters of Pelagius and his Followers, Woodbridge, 1991.

12 P.F. Beatrice, Tradux Peccati, Milano, 1978.

13 P.F. Beatrice, The Transmission of Sin, trans. by A. Kamesar, Oxford, 2013, Eng. edn, pp. 187240.

14 Beatrice, The Transmission of Sin, pp. 241-262.

15 I read this book in Italian when I stayed for research at the Augustinianum in Rome during my sabbatical term from 2007 to 2009. 
attracting attention in Europe and America, even though Beatrice's study has one weak point in that he could not prove the direct philological dependence of Augustine's doctrine of original sin on the Jewish Christians' encratite notions of hereditary sin.

A series of Pelagian studies by M. Lamberigts and A. Dupont has also become well known. Lamberigts' studies focused on Julian's understandings of the concept of God, ${ }^{16}$ origin of the soul, ${ }^{17}$ the nature of Adam, ${ }^{18}$ and grace, ${ }^{19}$ in comparison with Augustine's beliefs from a more objective viewpoint. Lamberigts stated in the conclusion of his christological study on Julian and Augustine that, "The starting points of Pelagian and Augustinian theology are so radically different that it is unfair to read and comment upon them through the eyes of the opponents." ${ }^{20}$ Lamberigts goes on to conclude, "The 'Pelagians' and 'Augustinians' had more in common than one might expect regarding most of the points that have been regarded as essential to 'orthodox' Christianity. A systematic, detailed study of this would be very helpful."21

A. Dupont also took a fair academic stance towards both Pelagians and $\mathrm{Au}-$ gustine. He also provided a precise positive evaluation of Pelagius' "theology" in his later study of Pelagius' christology in the Pauline commentary. ${ }^{22}$ After Dupont pointed out that research on Pelagius had long been dominated by negative evaluations and assumptions, he sought to correct such assertions as Pelagius was a moralist and not a theologian, that "Eigenstanden, an manchen Stellen ist er eher expliziter Ethiker als Theologe im strengsten Sinne. Das authentishce christliche Leben ist sein zentrales Thema, aber darin ist er stets zugleich Theologe. ${ }^{23}$ Dupont also sought to correct the assumption that Pelagius did not know the Holy Spirit, saying, "Pelagius betont die Notwendigkeit des Heiligen Geistes im Gebet. Die menschliche Fähigkiet zum Beten ist ohne

16 M. Lamberigts, "Julian of Aeclanum: A Plea for a Good Creator," Augustiniana, 38 (1988), pp. 5-24.

17 M. Lamberigts, "Julian of Aeclanum and Augustine on the Origin of the Soul," Augustiniana, 46 (1996), pp. 243-260. M. Lamberigts, "Julian d'Eclane et Augustin d'Hippone: deux conceptions d'Adam," Augustiniana, 40 (1990), pp. 393-435.

19 M. Lamberigts, "Julian of Aeclanum on Grace: Some Considerations," in: Studia Patristica, 27, ed. E.A. Livingstone, papers presented at the eleventh International Conference on Patristic Studies, Oxford 1991, Leuven, 1993, pp. 342-349.

20 M. Lamberigts, "Competing Christologies: Julian and Augustine on Jesus Christ," AugSt, 36 (2005), p. 194.

21 Lamberigts, "Competing Christologies," p. 194.

22 A. Dupont, "Die Christusfigur des Pelagius. Rekonstruktion der Christologie im Kommentar von Pelagius zum Römerbrief des Paulus," Augustiniana, 56 (2006), pp. 321-372. 
die Hilfe des Heiligen Geistes schwach."24 ("Pelagius emphasizes the necessity of the Holy Spirit in prayer. The human power for prayer is, without the help of the Holy Spirit, weak.") Dupont reached the conclusion that "Pelagius präsentiert eine herausfordernde Christologie ... Kurz, Pelagius versucht stets eine subtile Harmonie zwischen Gnade und menschlicher Freiheit, zwischen Glauben und Taten, zwischen Christus und Gesetz, zwishchen Antropologie, Moral und Theologie herzustellen. Darin spielt Christus eine wesentliche Rolle." ("Pelagius offers a distinguished christology .... In short, Pelagius always essentially tries to realize the harmony between grace and human freedom, between faith and deed, between Christ and law, between anthropology, morality and theology. In such harmony, Christ plays an essential role."25) The author of this article has been very much encouraged by the works of two old scholars, T. Bohlin and G. Greshake, and by current researchers, particularly Beatrice, Lamberigts and Dupont, because the direction of my studies since my dissertation has been similar to theirs.

For much of the long history of Augustine studies, an enormous number of biographies and micro-level theological studies up to macro-level historical wider perspectives have been published that paint a positive image of Augustine and a negative one of Pelagians. Nevertheless, holistically evaluating the theological and historical figures of the Pelagians, not as heretics but as authentic, orthodox Christian theologians, is overdue. Therefore, in this paper I would like to offer a multi-layered perspective, from the micro to the macro level, providing a wider perspective of Pelagians. Practically, I have to restrict the research focus to select aspects of Pelagius and Julian of Eclanum, particularly their significantly different theological and anthropological arguments from those of Augustine and his rhetorical tactics. In the following holistic descriptions from theological debates to historical-social incidents concerning the Pelagian controversy, several newly discovered facts will also be presented, and a unique ideology-critical hermeneutic approach adopted. I hope that this attempt will facilitate a more complete understanding of Pelagians' orthodoxy and the real reasons why Augustine won and the Pelagians lost the so-called Pelagian controversy.

\subsection{Ideology-Critical Hermeneutic by J. Habermas and A. Grillmeier}

The German social philosopher J. Habermas made clear that in excluding a social group from society in any period, "systematically distorted communica-

24 Dupont, "Die Christusfigur," p. 369.

25 Dupont, "Die Christusfigur," pp. 371-372. 
tion" is used. ${ }^{26}$ Habermas refers to such phenomenon in an ideology-critical hermeneutic, stating, "Language serves to legitimize relations for organized violence. So long as the legitimation doesn't speak about the violent relations, whose institutionalization the language makes possible, so long as the language expresses itself only in the legitimation, the language also becomes ideological."27 According to Habermas, even seemingly genuine theological or philosophical assertions can be "ideological", that is "political", particularly under certain political power pressure in a much wider range of power relations between opposing groups. Therefore, based on Habermas' hermeneutic, it is necessary to analyze theological assertions from the wider perspective of power relations. Theological arguments of Julian of Eclanum as well as those of Augustine are appropriate to being seen from such a political and ecclesiastical perspective.

Grillmeier adopted Habermas' ideas and adapted them to explore the excommunication of Nestorius in the eastern churches in the fifth century. Grillmeier clarified three rhetorical devices used in the excommunication of Nestorius, viz., 1) systematization, 2) schematization, and 3) rhetorical dialectic. ${ }^{28}$ In the first rhetorical device, systematization, the interlocutor picks up only part of an unclear or weak point from an opponent's entire argument and exaggerates only this unclear point by showing only as many similar assertions as possible, as if the part were the whole argument. In the second, schematization, the interlocutor points out characteristics peculiar to an opponent and combines them together to assert the worst possible heresy, for which someone had already been excommunicated in the past. Or conversely, the informant supports his own assertions by providing ideas of past great authorities as evidence, even if they cannot in fact offer any real evidence at all. In the third rhetorical device, the interlocutor makes an opponent confront another opposing heresy and then emphasizes the heretical character of the opponent by contrasting both the opponent and another heresy in overblown or exaggerated ways.

26 Hermeneutik und Ideologiekritik, ed. by J. Habermas, D. Heinrich, and J. Taubes, Frankfurt,1975, pp. 120-159.

27 J. Habermas, Zur Logik der Sozialwissenschaften, Frankfurt am Main, 1970, p. 287: "Sprache dient der Legitimation von Beziehungen organisierter Gewalt. Soweit die Legitimation das Gewaltverhältnis, dessen Institutionalisierung sie ermöglichen, nicht aussprechen, soweit dies in den Legitimationen sich nur ausdrückt, ist Sprache auch ideologish."

28 A. Grillmeier, Mit ihm und in ihm. Christologische Forschungen und Perspektiven, FreiburgBasel-Vienna, 1975, pp. 219-242 and 554-581. 
There have been no Pelagian studies published which have adopted Habermas' and Grillmeier's ideology-critical hermeneutic, even though it offers an appropriate and powerful method to understand the Pelagian controversy.

It is evident that all three rhetorical devices mentioned above were also present in the debate between Augustine and Julian of Eclanum. Nevertheless, seen comparatively, Augustine appeared to be much more tactical in using the three devices than the Pelagians. Before the battle between the two polemists, Augustine and Julian, Pelagius also suffered from such rhetorical tactics in the synod of Diospolis, held in 415. In the synod, Pelagius was accused in writing by two deposed Gallic bishops, Heros and Lazarus. ${ }^{29}$ They drafted their indictment of Pelagius with the help of Jerome and Orosius and submitted it to $\mathrm{Eu}-$ logius of Caesarea, who was the primate of Palestine. ${ }^{30}$ C.C. Burnet pointed out the problematic procedure and process of forming the synod indictments. Nevertheless, she did not point out an important misleading point in the quotation and interpretation, which I illustrate below. ${ }^{31}$ The third phrase of the three paragraphs, which contained the accusations by the two bishops, was cited from the letter of Pelagius. This phrase of Pelagius was taken as evidence that Pelagius had denied original sin, and that he had required of believers a perfect purity for obtaining their salvation. The phrase, which was cited and formed part of the accusation at the synod of Diospolis, was stated in the minutes as follows:

And in another book to her [following the prayer of our Lord and Saviour, and teaching how Christians should pray], he (Pelagius) says: 'The person who can say the following can properly raise his hands to God and pray |in good conscience: You know, Lord, how holy, innocent, and clean are the hands I extend to You, from all molestation, evil, and plunder, and

29 See E.D. Hunt, Holy Land Pilgrimage in the Later Roman Empire AD 312-46o, Oxford, 1982, pp. 206-207.

30 See R.J. Teske, S.J., "Introduction, The Deeds of Pelagius," in: The Works of Saint Augustine, A Translation for the 21st Century, part I, vol. 23: Answer to the Pelagians I, Hyde Park, NY, 1997, p. 321. Pelagii and Jerome's Dialogus adversus Pelagianos," AugSt, 34 (2003), pp. 153-173. 
how just, clean, and free of deceit, are the lips by which I pray to you for mercy. 32

Because Pelagius rejected those who held such opinions as shown in the paragraph, the synod took him to be orthodox not heretical. However, Augustine considered Pelagius' rejection to be evasive, pointing out that Pelagius falsely denied his authorship, although he himself had apparently written the phrase. ${ }^{33}$ Augustine referred neither to the contents of the phrase, nor its context in the books, nor the true meaning of Pelagius' defense. The sentence is clearly quoted from the letter Liber de uita Christiana of Pelagius. ${ }^{34}$ In this letter, Pelagius criticized the terribly immoral situations inside the churches at that time, and he fiercely attacked the reality of distinction and exploitation within the Roman church:

Do you consider him a Christian in whom there is no Christian act, in whom there is no righteous conduct, but evil, ungodliness and crime? Do you consider him a Christian who oppresses the wretched, who burdens the poor, who covets others' property, who makes several poor so that he may make himself rich, who rejoices in unjust gains, who feeds on others' tears, who enriches himself by the death of the wretched, whose mouth is constantly being defiled by lies, whose lips speak nothing but unworthy, foul, wicked and base words, who, when ordered to distribute his own possessions, seizes others' instead? And a man of this kind has the audacity to go to church and thoughtlessly and inappropriately stretch out his impious hands, stained as they are with illicit plunder and the blood of innocents, and from that defiled and profane mouth with which

32 For the reconstructed acts of the synod of Diospolis, see W. Dunphy, SVD, The Acts of the Synod of Diospolis: Text, translation, and notes, (Academia [Humanities, Social Sciences], 67), Nanzan University, 1998, p. 190 : "Et in alio ad ipsam libro [post orationem domini et saluatoris nostri, docens quemadmodum debeant sancti orare] ait: 'ille ad deum digne eleuat manus, ille orationem bona conscientia effundit, qui potest dicere: tu nosti, domine, quam sanctae et innocents et mundae sunt ab omni molestia et iniquitate et rapina quas ad te extendo manus, quemadmodum iusta et munda labia et ab omni mendacio libera, quibus offero tibi deprecationem, ut miserearis."”

33 Augustine, De gest. Pel. 6.16; NBA 17/2.46.

34 On the question of authorship, see R.F. Evans, Four Letters of Pelagius, New York,1968, pp. 18-20; W. Dunphy, SvD, "A Manuscript Note on Pelagius' De vita Christiana (Paris, BN Lat. 10463)", Aug, 21 (1981), pp. 589-591; and Rees, The Letters, pp. 105-106. 
a little before he has been uttering either false or base words pours forth his prayers to the Lord as if conscious of no evil in himself. ${ }^{35}$

Just after these criticizing phrases, the citation quoted at the synod of Diospolis follows: "The person who can say the following can properly raise his hands to God and pray in good conscience: You know, Lord, how holy, innocent, and clean are the hands I extend to You from all molestation, evil, and plunder, and how just, clean, and free of deceit, are the lips by which I pray to you for mercy." 36 It is quite apparent that Pelagius did not intend to assert that there was really a person who did not sin by his own will, nor intend to reject infant baptism, by which original sin was removed, a result of his theological speculation. His main purpose was to criticize the real situation inside the Roman church, in which nominal Christians would not know Jesus' teaching, but rather the nominal Christians oppressed the weak even within these very churches. ${ }^{37}$ Severely criticizing such immoral discrimination inside the churches as a kind of a social structural evil, Pelagius wanted to carry out a reform not only of the believers but also of the churchmen at that time. Nevertheless, taking the opportunity of Augustine's claiming Pelagius' rejection as evasion, it is not able to be denied that Pelagius was thought of as a liar and this "evasion" affected his excommunication. Nevertheless, on the part of Pelagius, it was a kind of a mean trick to pick up only his assertion on "pure hand" totally apart from the context of criticizing the oppression of the weak believers by such arrogant nominal

Pelagius, Liber de uita Christ. 11.1; PL 40.1041 : "Nam tu illum christianum putas, in quo nullus christianitatis est actus, in quo conversation nulla justitiae est, sed nequitia, impietas et scelus? Illum Christianum putas, qui opprimit miserum, qui pauperem gravat, qui res concupiscit alienas, qui ut se divitem faciat, plures efficit indigentes, qui lucris gaudet injustis, qui de alienis lacrymis cibum capit, qui miserorum ditatur interitu, cujus os assidue mendacio violatur, cujus labia nonnisi indigna et obscena et scelesta loquuntur et turpia, cui cum jubeatur distribuere sua, invadit aliena? Et ad ecclesiam talis audenter accedit, et temere et importune expandit impias manus, illicito raptu et insontium cruore violatas: et ore illo polluto atque sacrilego, quo fuerat paulo ante aut falsa locutus aut turpia, preces ad Dominum, quasi nihil sibi mali conscius fundit." Eng. trans. in Rees, The Letters.

36 Pelagius, Liber de uita Christ. 11; PL 40.1042: "Ille autem ad Deum merito extollit manus, ille preces bona consceintia fundit, qui potest dicere, Tu nosti, Domine, quam sanctae, quam innocents, quam purae sint ab omni fraude et injuria et rapina, quas ad te expando, manus; quam justa, quam imamculata labia et ab omni mendacio libera, quibus tibi, ut mini miserearis, preces fundo."

Concerning positive evaluations on Pelagius, see A. Garcia, Pelagius and Christian Initiation: A Study in Historical Theology, Ann Arbor, Mich., 1979; and Dupont, "Die Christusfigur," pp. 321-372. 
Christians in the Roman church. It seemed to be absolutely obvious to Pelagius that he rejected his authorship of the phrase, because it was cited completely in disregard of his original intention. We can take this measure of persecuting Pelagius for the first rhetorical device mentioned above as "systematization", that is, a rhetorical device for picking up only one part or section from an entire context and original intention and exaggeratedly combining it with another completely different theological argument.

\section{$3 \quad$ Rhetorical Logic and Crucial Opinions of Both Polemists}

Augustine's last work, Opus imperfectum, ${ }^{38}$ which consists of controversial assertions of both Julian's and Augustine's quite different arguments, is completely filled with the above mentioned three rhetorical devices. The important point to note is, although Julian also used such rhetorical devices, it was Augustine who excelled much more in using these devices in order to defend his own arguments and attack Julian's counter assertions. Julian, the 45-year-old bishop of Eclanum, fought against the over 75-year-old African bishop Augustine with unrestricted energy. Augustine also showed little restraint, even uttering vulgar language in blaming Julian, just as Julian attacked Augustine with his own coarse words. Finally, this last work of Augustine swelled to about 1000 pages and remains incomplete. This work, probably written in Augustine's very last years, was not translated into any modern languages until the end of the twentieth century. ${ }^{39}$ This significant controversy was between two men who were not just professional theologians but also skilled rhetoricians.

\subsection{Sexual Desire as an Evil of Corrupted Nature in Augustine's View}

From the beginning of Opus imperfectum until the end, Augustine continued to insist again and again that, since Adam's fall, human nature was corrupt. Augustine emphasized that, as a result of this corruption, all human beings have sexual desire, which is a diabolical evil. ${ }^{40}$ In Augustine's opinion, sexual

38 Augustine, Op. imp.; NBA 19.

39 The Works of Saint Augustine: A Translation for the 21st Century: part I, vol. 25: Answer to the Pelagians, III: Unfinished Work in Answer to Julian, trans. by R.J. Teske, Hyde Park, NY, 1999. For recent important research, see M. Lamberigts, "Recent research into Pelagianism with Particular Emphasis on the Role of Julian of Aeclanum," Augustiniana, 52, (2002), pp. 175198.

40 Augustine, Op. imp. 2.31; NBA 19/1.228: "Quolibet pruritu libidinem, id est, concupiscentiam carnis laudes, dicit eam Iohannes apostolus a Patre non esse, sed ex mundo esse; propter quam recte dicitur diabolus princeps mundi esse; nam scimus quod mundum 
desire is a natural defect inherited in human nature from Adam; that is, it is the so-called "original sin". ${ }^{41}$ Even newborn babies cannot avoid inheriting this original sin, which functions not only as a sin in and of itself but also as a penalty. ${ }^{42}$ In order to remove this original sin, all newborn babies should receive infant baptism, without which they could not enter into heaven after death. ${ }^{43}$

It is apparent that Augustine viewed sexual desire as quite negative, repeatedly describing such desire with such epithets as shameful and diabolical. Augustine's ultimate opinion was that human sexual desire was evil, in so far as it was not used for the sake of procreation. ${ }^{44}$ Augustine cited the names of Irenaeus, Basil, Gregory of Nazianzus, and John Chrysostom to support his theory of original sin..$^{45}$ Moreover, Augustine cited Romans 5:12 as apparent biblical evidence to support his notion of original sin, just as we will see in detail later. ${ }^{46}$ Augustine saw Julian as "a fan of sexual desire", and required Julian "to clothe your shameful darling with the honorable name of marriage". ${ }^{47}$

\subsection{Sexual Desire as a Part of a Healthy Nature in Julian's View}

In opposition to Augustine's quite negative evaluation of sexual desire, Julian asserted over and over again that sexual desire was a natural part of human nature, that there was nothing evil in human nature, and therefore that sexual

deus fecerit. Hoc ergo malo concupiscentiae carnis bene utitur pudicitia coniugalis eiusque mali reatum a nascentibus tractum solvit regeneratio spilitalis."

Augustine, Op. imp. 3.177; NBA 19/1.598: “... dicimus eam [carnis concupiscentiam] vitium esse substantiae bonae, quod in nostram naturam per praevaricationem primi hominis versum est, quod dicunt catholici Christiani; eiusque mali usus licitus et honestus liberorum procreandorum causa approbatur a nobis sicut a catholicis Christianis."

Augustine, Op. imp. 1.57; NBA 19/1.: "... profecto intellegeres, sic imputari generatis parvulis iniustitiam primi hominis ad subeundum suplicium ...”; and 4.121; NBA 19/2.816-818: “... 'per quae in primordia naturae suae qui baptizati fuerint parvuli a militia reformantur.' Dic, Iuliane, a qua militia, si non trahunt originale peccatum."

Augustine, Op. imp. 5.9; NBA 19/2.868: "Originale peccatum propterea significatius quam naturale dicimus, ut non divini operas, sed humanae originis intellegatur; maxime propter illud significandum, quod per unum hominem intravit in mundum ...."

Augustine, Op. imp. 2.42; NBA 19/1.238: "Pudenda enim libido nisi aut peccato exorta, aut peccato vitiata esset, pudenda non esset; et aut nulla esset omnino ...”; and 5.13; NBA 19/2.878: “... sed dico eos non agere opus daiboli, quando utuntur libidine non propter libidinem, sed propter propaginem."

45 Augustine, Op. imp. 1.52; NBA 19/1.56-58; and 4.73; NBA 19/2.734.

46 E.g., Augustine, Op. imp. 2/36-37; NBA 19/1.232-234.

47 Augustine, op. imp. 2/122; NBA 19/1.312: "Erubesce; tu es ille laudator libidinis. Erubesce, inquam." and 4.19; NBA 19/2658: “... ut vestias pudendam susceptam tuam nominee honesto nuptiarum?" 
desire was never at all an evil. ${ }^{48}$ Julian repeatedly emphasized that the question was not the existence of sexual desire itself, but that excessive sexual desire caused sin. ${ }^{49}$ According to Julian's argument, Adam could not have changed human nature, therefore, not only Adam but also Christ had their own natural sexual desire just as all human beings do. Julian denied the existence of original sin so he asserted only sins committed by free will should be called sins. ${ }^{50}$ Julian recognized the necessity of infant baptism; nevertheless, he argued that the purpose of the liturgy was not to remove original sin but rather to endow infants with various divine gifts such as spiritual enlightenment, their adoption as children of God, and ultimately to ensure their transformation into members of the body of Christ through the liturgy. ${ }^{51}$

Julian took Augustine's understanding that sexual desire was an evil to be the same idea as Mani's. Julian showed that the Manichaean doctrine of an evil nature is explicitly taught in various passages from Augustine's writings. ${ }^{52}$ Here, it is quite noteworthy that Julian criticized not only Augustine but also his African precursors Tertullian and Cyprian as traducianists, who accepted hereditary original sin. ${ }^{53}$

Finally, Julian accused Augustine of being docetism in his view of Christ's human nature just like the heresy of Appolinaris. ${ }^{54}$ The Apollinarists thought that Christ had no human senses in his body and was incapable of suffering.

48 E.g., Augustine, Op. imp. 4.42; NBA 19/2.690: "Nos autem docuimus voluntatem illam naturaliter sexibus inditam, tam malam non esse, quam ad Dei operam pertinentem." and esp. 3.159; NBA 19/1.580: "Malum igitur naturale esse non potest ac per hoc nec rea ulla naturaliter creatura nec malus auctor. Malum quippe non exstantis invenitur naturae, sed sicut omnis creatura, in quantum conditur, bona est, ita et Deus, naturarum auctor bonarum, nullo operis sui crimine maculatus per omnia bonus probatur."

49 E.g., Augustine, Op. imp. 4.41; NBA 19/2.688: "Igitur non modum, non genus; sed excessum eius culpat Deus, qui de insolentia liberae voluntatis exoriens haud statum naturae, sed meritum agentis accusat."

$50 \quad$ Augustine, Op. imp. 4.59; NBA 19/2.722: "Claruit enim nihil minus de natura hominum, salvatoris corpus habuisse." and 2.201-202; NBA 19/1.390: "Apparet ergo apostolum peccatum ante legem liberae voluntatis, post legem autem praevaricationem totidem liberae voluntatis arguer ... Ac per hoc constat nihil eum de peccato traducis elocutum, quae quamvis copiosa essent, ad probandum nihil apostolum de naturali, quod esse non potest ...."

$5^{1} \quad$ Augustine, Op. imp. 1.53; NBA 19/1.58: "Hanc igitur gratiam, per quam reis venia, illuminatio spiritalis, adoptio filiorum Dei, municipatus Hierusalem caelestis, sanctificatio atque in Christi membra translation, et possessio regni caelorum mortalibus datur ...."

52 Particularly, Augustine, Op. imp. 3.153-158; NBA 19/1.572-580.

53 Augustine, Op. imp. 6.5; NBA 19/2.1026-1030.

54 Augustine, Op. imp. 4.47-49; NBA 19/2.700706. 
Julian strongly criticized Augustine for his declaration in his work De nuptiis et concupiscentia 2.5.14 that Christ, whom the Catholic faith believes to be a true man in all respects, did not have in his flesh the concupiscence of the flesh. ${ }^{55}$ According to Julian, if Christ did not have the same sexual desire as ours as human beings, Christ could not be for us an example for avoiding sin and practising virtue and that Christ teaching us to follow his example was essentially misleading. ${ }^{56}$ Julian argued that the idea of natural defect as evil would not only remove all zeal for discipleship, but would also diminish the praise offered to Christ. ${ }^{57}$ It is quite interesting for us that both Julian and Augustine recognized themselves as Catholic, but the contents of their Catholic christology were quite different in their interpretations of "true man". Julian's true man of Christ was the Christ who could show a moral example for us to imitate to control our human sexual desire, as Christ as a true man had the same sexual desire as other humans. For Augustine, on the other hand, Christ as a true man had a perfect human nature completely free from original sin, from any evil. Nevertheless, Augustine's understanding of Christ as a true man was contradictory, particularly in how it saw sexual desire, which Julian criticized fiercely.

\subsection{Polemical Opposing Fronts between Augustine's and Julian's Theologies: Sexual Desire and Christology}

Putting the above opposing arguments in order, we can consider the critical core points in Opus imperfectum to be evaluation of human sexual desire and its christological interpretation. In Augustine's doctrine of original sin, sexual desire was a natural defect inherited in human nature from Adam. Therefore, sexual desire was an evil, and was a natural defect. On the other hand, for Julian, sexual desire was a natural part of human nature, and there being nothing evil in human nature so sexual desire was never an evil at all. As the result of these arguments, for Augustine, Christ had no evil, therefore, he did not have sexual desire, which protested against his will. On the contrary, for Julian, Christ had just the same human nature as everyone else, in order to be a perfect example of humanity, therefore Christ also had sexual desire.

M. Lamberigts, describing much more in detail these distinguished differences on sexual desire and christological interpretation, pointed out that Christ was medicus in Augustine's christology. ${ }^{58}$ Lamberigts stressed that Christ being not medicus and the human nature being never damaged, "there

55 Augustine, Op. imp. 4.45; NBA 19/2.698-700. See Augustine, De nupt. et conc. 2.5.14; NBA 18.100.

56 Augustine, Op. imp. 4.50; NBA 19/2.706-708.

57 Augustine, Op. imp. 4.87; NBA 19/2.750-754.

$5^{8} \quad$ Lamberigts, “Competing Christologies," pp. 171-172. 
would have been no need for salvation or a Redeemer."59 Based on such christological understanding, in Lamberigts' opinion, for Augustine, "Christ's radical victory over sinful (sexual) desire is an inspiration for us in our struggle against it", 60 just as Christ as medicus and redeemer. "Julian's idea of exemplum is not enough for Augustine. He considered it to be too external."61

P. Burnell, however, criticizing defenders of Pelagians, for example, K.E. Kirk, E. Pagels, and P. Gorday, positively evaluated Augustine's interpretation of sexual desire. Burnell concluded, "concupiscence is a door to salvation, for it makes us accept that we are not morally independent of God," as concupiscence is for Augustine, "an important providential vehicle of grace." ${ }^{2}$ As a critique of Kirk, Pagels, and Gorday, Burnell argued that they had made mistakes in emphasizing "before Augustine, most of the Greek Church Fathers thought themselves immediately capable of practicing perfection." ${ }^{63}$ Burnell argued that the Greek Church Fathers before Augustine, like Origen, Gregory of Nyssa, and even John Crysostom, also did not assert such possibility of practical perfection. ${ }^{64}$ On the contrary, they held the idea, just like Augustine, that the mass of morally feeble Christians, apart from a few blessed, perfect saints, had to rule out the notion that baptism ordinarily brought complete moral liberation. ${ }^{65}$ In Brunell's opinion concerning human nature and moral development, "what Gregory [of Nyssa] says here is in essential the same as the Augustinian position." 66 Also in the view on John Chrysotom, Burnell stressed, "Chrysostom, too, therefore, includes baptized Christians among those to whom the Pauline passage applies. Christians remain concupiscent; they remain dependent on grace." ${ }^{\prime 67}$ In short, in such an uncritical interpretation of Augustine's referring to Greek fathers, Augustine adopted authentically Greek traditions of the helpless and feeble nature of humanity. Augustine was the successor of these old traditions, ultimately developing a negative view of human sexual desire, finalized in the doctrine of original sin.

On the other hand, in Beatrice's study, Augustine was a successor of Jewish Christian Encratism or Messsalianism, which combined a kind of hereditary sin with sexual desire. Quite different from Burnell's interpretation, Beatrice

59 Lamberigts, "Competing Christologies," p. 181.

$60 \quad$ Lamberigts, "Competing Christologies," pp. 173-174.

61 Lamberigts, "Competing Christologies," p. 175.

62 P. Burnell, "Concupiscence and Moral Freedom in Augustine," AugSt, 26 (1995), pp. 6o-61.

63 Burnell, "Concupiscence," p. 50.

64 Burnell, "Concupiscence," pp. 52-59.

65 Burnell, “Concupiscence," p. $5^{6 .}$

66 Burnell, "Concupiscence," pp. 56-57.

67 Burnell, “Concupiscence," p. 59. 
asserted that the eastern Greek fathers almost objected to the idea of such Encratism, the Messalian hereditary sin. I cannot accept Burnell's interpretation, but rather, supporting Beatrice's study, I would like to sum up the crucial points of the controversy between Augustine and Julian in Opus imperfectum in the following two different Christian traditions: supporters of hereditary sin combined with sexual desire (Jewish Christian Encratism or Messalianism and Augustine), and anti-supporters of hereditary sin combined with sexual desire (Greek church fathers and Pelagians).

Julian also used the three rhetorical devices, particularly schematization, to criticize Augustine's christology as the same as Appolinarian docetism. We can also recognize the device in Julian's critique, that Augustin's doctrine of original sin, including his view on sexual desire, was the same as Manichaeans. Nevertheless, so long as we observe Augustine's biblical quotation, his reference to the names of Greek fathers, and also his sticking to a "Catholic" viewpoint, we cannot help but determine that Augustine succeeded much more in using the tactical device of rhetoric than did Julian.

\subsection{Augustine's Misunderstandings on Biblical text and his Rhetoric of Calling the Name of Greek Fathers}

Polemicizing against Julian's denial of original sin, Augustine repeatedly quoted Romans 5:12, "... thus death spread to all men, because all sinned ..." (et ita in omnes homines mors pertransiit, in quo omnes peccaverunt ...). It is already well known that Augustine took in quo to mean "in Adam" so he read the text as "in Adam, all sinned." On the contrary, Julian took in quo as a conjunction meaning "because" so he read this sentence as "because all sinned". Nowadays, Julian's interpretation is recognized as the correct reading by most biblical scholars. ${ }^{68}$ As we noted before, Augustine used the names of well-known Greek church fathers such as Irenaeus, Basil, Gregorius of Nazianzus, and even John Chrysostom as authorities who supported his theory of original sin and that infant baptism cleansed original sin. ${ }^{69}$ Nevertheless, despite Burnell's

68 For example, M. Wolter, Der Brief an die Römer, Teilband 1: Rom 1-8 (EKK, Bd 6), Ostfildern, 2014, p. 344: "In der neueren exegetischen Literatur geht man davon aus, dass der Bezug

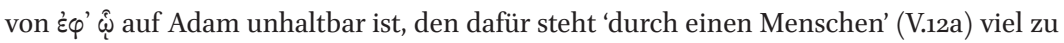
weit von ihm entfernt. In den meisten neueren Kommentaren und sonstigen Interpreta-

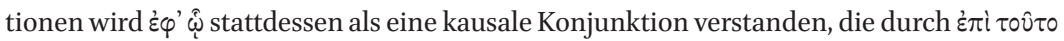
ö $\tau$ ('aus welchem Grund' oder 'weil') umschreiben werden könne."

69 See, note 14. Concerning Augustine's use of traditional texts as authorities, M. Lamberigts, "Augustine's Use of Tradition in the Controversy with Julian of Aeclanum," Augustiniana, 60 (2010), pp. 11-61, collected a vast number of first sources, not only of Latin fathers but also of Greek fathers. In the use of Scripture and tradition, Lamberigts explained and 
critique, not one of the above-named fathers recognized original sin as Augustine interpreted it and not one of them thought that even newborn babies genetically inherited Adam's original sin. Moreover, none of the fathers thought that sexual desire was evil, which was also a penalty as well as a sin.

For example, Augustine cited the name of Irenaeus as the first witness for his theory of original sin. Nevertheless, Irenaeus' optimistic view on human nature and God's history for human salvation did not acknowledge any space for Augustine's theory. Irenaeus insisted on the existence of the free will. ${ }^{70}$

It should be noted that the Cappadocian fathers had a tendency to idealize Adam's nature in paradise before his fall. Therefore, Basil and Gregory of Nazianzus also emphasized sexual desire and the death of the human body as the result of Adam's fall. Nevertheless, both of these fathers did not deny the power of human free will, which they believed remained part of human nature; moreover, both of them recognized only the result of Adam's fall including human sexual desire but not original sin that at the same time has its own penalty, concluding that newborn babies were completely innocent. ${ }^{71}$ Finally, for Basil and Gregory of Nazianzus also, having sexual desire was one of the results of Adam's fall, but sexual desire was not considered to be a penalty of original sin with a hereditary character, unlike Augustine. John Chrysostom said, "Adam

evaluated Augustine's consistency and pointed out (p. 6o), "With regard to that Eastern tradition, it should be repeated that Augustine mainly is dependent on translations." In particular, Lamberigts' "survey of the way in which Augustine presents the individual doctors" (p. 14) was also very significant and useful for this article.

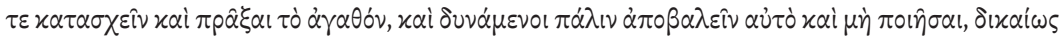

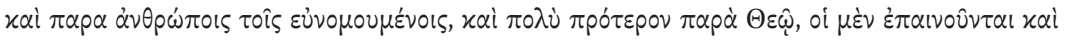

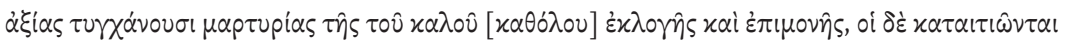

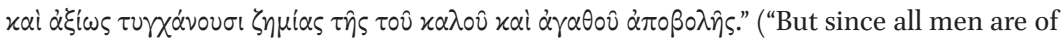
the same nature, able both to hold fast and to do what is good; and, on the other hand, having also the power to cast it from them and not to do it,--some do justly receive praise even among men who are under the control of good laws (and much more from God), and obtain deserved testimony of their choice of good in general, and of persevering therein; but the others are blamed, and receive a just condemnation, because of their rejection of what is fair and good"; A. Roberts's and W.H. Rambaut's translation from Latin, 1868; online at <http://www.earlychristianwritings.com/irenaeus.html >).

Basil of Caesarea, De Spir. 14.31; PG 32.969; Basil of Caesarea, Hom. super Ps. 29.5; PG 29.317; Gregory of Nazianzus, Or. 38.12; PG 36.324; Gregory of Nazianzus, De se ipso 45.95-100; PG 37.136o; and Gregory of Nazianzus, Or. 19.14; PG 35.106o-1061. Sin by free will: Basil of Caesarea, Hom in hex. 2.5; SC 26.160-166; Basil of Caesarea, Reg. brev. tract. 75; PG 31.11331136; Gregory of Nazianzus, Or. 14.25; 16.15; 19.13-14; and 37.13 and 20; PG 35.892, 953, 106oo61 and 36.297 and 305. Innocence of infants: Gregory of Nazianzus, Or. 40.23; PG 36.389. 
committed that great sin and condemned the whole human race in common," which Augustine quoted. ${ }^{72}$ However, John recognized only the death of the human body as a result of Adam's fall, and John did not acknowledge any inherited sin, which contaminated newborn babies. John said, "The souls of the righteous people are within God's hand (Wis 3:1). And if the souls of the righteous, then, those of the infants too, because they are not wicked, whereas those of the sinners are straightway led away hence."73

As we referred to before, making clear the Encratite-Messalian idea of hereditary sin combined with a negative view on sexual desire before Augustine, Beatrice concluded that "the Greek Fathers opposed this doctrine from the beginning with all of their theological and pastoral authority. They felt it to be alien to the main body of orthodox belief, and therefore judged it to be heretical."74 The more we know of the indifference of Greek fathers to hereditary sin combined with sexual desire, the more we can be convinced that $\mathrm{Au}$ gustine effectively used rhetorical devices in order to assert his orthodoxy.

\section{Political and Ecclesiastical Perspectives of Augustine's and Julian of Eclanum's Theological Arguments}

Initially, it may seem to be a little strange to provide a political perspective on theological arguments not of a politician but of a clergy person. Nevertheless, consistent with Habermas' ideology-critical hermeneutic, if a theological argument is located in strongly political power balances at the macro level, we cannot help seeing a political perspective even in genuine theological statements at the micro level. In these contexts of critical hermeneutics, the concept of "political" means not directly judicial or social behavior or incidents, but more daily strategic, tactical speech and deeds. Nevertheless, such "strategic or tactical" speech and deeds at the micro level also assume a "political" character, under pressure or influence from external "real political" behavior or incidents, and ultimately they are in fact connected with such "real political" matters at the macro level in real political and ecclesiastical perspectives.

\footnotetext{
72 Augustine, Op. imp. 1.52; NBA 19/1.56: "Adam peccavit illud grande peccatum et omne hominum genus in commune damnavit." See John Chrysostom, Ep. ad Olymp. 10.3; SC 13.156 .

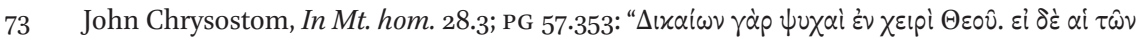

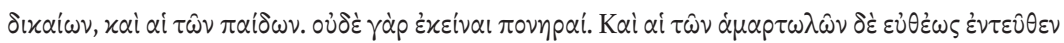

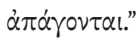

Beatrice, The Transmission of Sin, p. 219.
} 


\subsection{Augustine's Hazardous Interpretation of Sexual Desire and its Political Dimension}

According to Augustine, human nature is damaged by Adam's transgression and, so far as human nature is not healed by God's special grace, it remains a corrupted, sick nature. In Augustine's view, human nature including free will is also necessary to make up for this defect, and is healed by God's grace. ${ }^{75}$ Only Christians' free will can be liberated by Christ's grace, nevertheless, sexual desire as an evil remains in the nature of Christians. ${ }^{76}$ Augustine tried to solve this contradiction through Paul's concept of "a righteous man at the same time a sinner."77

75 Augustine, Ad Simplic. 1.1.11; NBA 6/2.290: "Certe enim ipsum velle in potestate est, quoniam adiacet nobis ; sed quod perficere bonum non est in potestate, ad meritum pertinet originalis peccati. Non enim est haec prima natura hominis sed delicti poena, per quam facta est ipsa mortalitas quasi secunda natura, unde nos gratia liberat conditoris subditos sibi per fidem.”; and Augustine, Op. imp. 3.177; NBA 19/1.: “... sed dicimus eam vitium esse substantiae bonae, quod in nostrum naturam per praevaricationem primi hominis versum est, quod dicunt catholici christiani ...."

76 Augustine, Op. imp. 2.31; NBA 19/1.228: "Quolibet pruritu libidinem, id est, concupiscentiam carnis laudes, dicit eam Ioannes apostolus a Patre non esse, sed ex mundo esse; propter quam recte dicitur diabolus princeps mundi esse. Nam scimus quod mundum Deus fecerit. Hoc ergo malo concupiscentiae carnis bene utitur pudicitia coniugalis; eiusque mali reatum a nascentibus tractum solvit regeneratio spilitalis."

77 Augustine, De nat. et grat. 38.45; NBA 17/1.432-434: "Hoc peccatum, id est, hunc vitiosae affectionis adpetitum, qui magna ex parte frenarunt, ut non oboedirent desideriis eius nec exhiberent ei membra sua arma iniquitatis, etiam iusti appellari meruerunt et hoc adiutorio gratiae Dei. Verum quia saepe in leuissimis et aliquando incautis obrepit peccatum, et iusti fuerunt et sine peccato non fuerunt." See P. Gorday, Principles of Patristic Exegesis: Romans 9-11 in Origen, John Chrysostom, and Augustine (Studies in the Bible \& Early Christianity), New York, 1983, pp. 1-135; Concentrating on the precise connection of Romans chapters 9-11 with the first eight chapters of Paul's letter, Gorday surveys the ways in which Pauline exegesis has been understood and represented in patristic exegesis; also see E. Pagels, Adam, Eve and the Serpent, New York, 1988, pp. 143-144: "When we actually compare Augustine's interpretation with those of theologians as diverse as Origen, John Chrysostom, and Pelagius, we can see that Augustine found in Romans 7 what others had not seen there - a sexualized interpretation of sin and a revulsion from 'the flesh' based on his own idiosyncratic belief that we contract the disease of sin through the process of conception. Other theologians assumed that Paul used these words to dramatize the situation of one who, still unbaptized and unredeemed, lacks hope $<\ldots>$. Augustine alone applied the despairing expressions of the previous passage to the baptized Christian; other readers assumed that the triumphant and joyful note of the rest of the chapter expressed Paul's experience of his life in Chrsit." 
From this argument, Augustine's kind of hazardous interpretation of sexual desire developed. In the case of Christians, sexual desire is "no longer sin, but still called so. ${ }^{78}$ For Christian married couples also, sexual desire is necessary for procreation. In the case of Christian couples deepening their love of God, sexual desire is "no longer charged of sin". ${ }^{79}$ Sexual desire remains also in Christian married couples as "a kind of affection with a negative quality" 80 where "it remains as an act, but disappear as a sin." 81 Augustine argued again and again in Opus imperfectum that human beings received sexual desire as an evil in consequence of human nature's defects due to Adam's sin. In addition to this, Augustine emphasized that Christian couples made use of this evil of sexual desire for good, that is, for procreation. Therefore, Augustine argued that Christ had no sexual desire. ${ }^{82}$

Concerning different evaluations of human sexual desire, we can recognize that Augustine and Julian were dealing with Christians and pagans in quite different ways. Particularly in the case of Augustine, the hazardous interpretation mentioned above has not only a theological meaning but also important "political" suggestions, in the light of pagan policy, from the perspective of ideology-critical hermeneutic. For Augustine, sexual desire was a kind of deficit, that is, a sick nature, and in that sense an evil, so therefore pagan couples' sexual desire should remain an evil because it was not healed by God's special grace from outside. On the contrary, as we argued above, Christian couples' sexual desire should also remain in the act, but their sexual desire is not accused of being an evil anymore because its guilt is removed and they use the desire and the act for good, that is, for procreation. In Augustine's argument on sexual desire, it is very obvious that there is a clear distinction between Christians and pagans..$^{83}$ On the other hand, for Julian, there was not any discrimi-

78 Augustine, Con. ep. Pel. 1.13.27; NBA 18.214: “... iam non sit peccatum, sed hoc vocetur ....”

79 Augustine, De nupt. et conc. 1.25.28; NBA 18.62 : “... ut peccatum non imputetur ...."

$80 \quad$ Augustine, De nupt. et conc. 1.25.28; NBA 18.62: “... affectio quaedam malae qualitatis ....”

81 Augustine, De nupt. et conc. 1.26.29; NBA 18.62: “... manet actu, praetereat reatu ....”

82 Augustine, Op. imp. 4.29; NBA 19/2: "Visus ergo sensus carnis est bonus: concupiscentia vero carnis motus est malus. Quo malo si bene utitur coniugatus, non eum bonum facit; sed operi bono servire compellit. Facit enim nonnisi boni aliquid et per ipsum, si nihil faciat propter ipsum; si autem faciat aliquid, sed tamen in coniuge propter ipsum, non ei veniam daret apostolus gratia nuptiarum, si non agnosceret esse peccatum."; and 3.177; NBA 19/1. "... eiusque mali usus licitus et honestus liberorum procreandorum causa approbatur a nobis sicut a catholicis Christianis."

83 Augustine could not value any virtues of pagan philosophers at all. See A. Dupont, "The Relation between Pagani, Gentes and Infideles in Augustine's Sermones ad pomulum: A Case Study of Augustine's Doctrine of Grace," Augustiniana, 58 (2008), pp. 95-126, at 
nation between Christians and pagans in his assertion that human nature including sexual desire was not corrupted and that sexual desire was defined as an evil neither for Christians nor for pagans. ${ }^{84}$ It is very important for us to be able to consider these quite different evaluations of sexual desire by Augustine and Julian also as a political difference, because the Roman emperor at that time had declared the excommunication of pagans and Christian heresies, aiming at strongly promoting pagan conversions to Christianity. 85

Considering Augustine's apparent discrimination between Christians and pagans in dealing with theological evaluation on sexual desire, and Julian's emphasis on equality in natural conditions including sexual desire, Augustine's rhetorical superiority, particularly in terms of political influence, is obvious. Under pagan-controlled policy in the Roman empire, it could be argued that Augustine's rhetorical tactics and its supremacy was far more advantageous than those of Julian.

\subsection{Different Frameworks, which Regulated Different Anthropologies}

We have clarified the crucial theological points of the controversy between Augustine's and Julian's two different types of Christians based on Beatrice's study, that is, supporters of hereditary sin combined with sexual desire (Jewish Christian Encratism or the Messalianism and Augustine), and anti-supporters of hereditary sin (Greek church fathers and Pelagians). Nevertheless, in order to explain the reason for the controversy between Augustine and the Pelagians,

p. 125: "Dogmatically, Augustine remains strict in his sermons: virtues and salvation are not available to non-Christians."

84 E.g., Augustine, Con. Iul. 4.3.14; NBA 18.674: “... occurentem, deinde questionem tacitus nolui praterire, quid dicendum sit, cum videntur etiam nonnulli impii pudice cum conjugibus vivere. 'Soletis,' enim, 'negantes Dei dona esse virtutes quibus recte vivitur, et eas naturae voluntatique humanae, non gratiae Dei tribunes, hoc uti argumento, quod eas nonnunquam habeant infidels:' (De nup. et conc. 1.3.4) ita connates evacuare quod dicimus, neminem recte vivere, nisi ex fide per Jesum Christum Dominum nostrum, unum Dei et hominum mediatorem ..."; and Augustine, Op. imp. 1.83; NBA 19/1.116: "IUL. Quod ut breviter absolvatur, possibilitas est ad hoc solum excubans, ne homo vel in peccatum a quoquam impellatur, vel a peccato abstrahatur, voluntate captiva; quam non posse capi, si dedi ipsa noluerit, testatur fortitudo, cuius Iacerti in contemptu dolorum et per gentiles et per Christianos assidue claruerunt."

85 For imperial promulgations against pagans in 381, see Cod. Theod. 16.10 .7 (Codex Theodosianus, vol. 1: Theodosiani Libri XVI cum constitutionibus Sirmondinis, part 2: Textus cum apparatu, ed. by Th. Mommsen and P. Krüger, Berlin, 1990, p. 899); in 382, 16.10.8 (Mommsen and Krüger, 1/2.899); in 385, 16.10.9 (Mommsen and Krüger, 1/2.899); in 392, 16.10.12 (Mommsen and Krüger, 1/2.900-901); against heresies: 16.5.6-15 (Mommsen and Krüger, $1 / 2.856-861)$. 
we have to add two further opposing schemas to the first schema concerning sexual desire, that is, different theological frameworks and different ecclesiastical views.

Considering Augustine's theory of original sin and his view on human sexual desire, a kind of structural resemblance is evident in several aspects of human nature, that is, "deficit" and "helplessness". According to Augustine, human free will itself is not sufficient to do good, because human free will was damaged or suffering from a significant loss since Adam's first sin. Human unfree will should be liberated by God's special grace, in order to be able to do good. Human sexual desire remains an evil without making use of it for procreation. Human nature is seen as corrupted itself by original sin; therefore, it should be recovered by the special healing grace being poured out from God. ${ }^{86}$ In all of its aspects, as human nature itself always lacks some important elements, it needs external power from outside of the human being. In other words, human nature is suffering from a dysfunction, and it can do nothing good of itself without the special healing grace from God.

We can recognize that the neo-Platonic understanding of evil as privation of good, by which Augustine was once freed from the Manichaean dualistic view of the world, occupied Augustine's way of thinking on evil consistently until the end of the Pelagian controversy in the last part of his life. ${ }^{87}$ Although he did not apply the entire philosophical contents of neo-Platonist Plotinus to his anthropology, ${ }^{88}$ Augustine adopted at least the fundamental structure con-

86 Augustine, Ad Simplic. 1.1.14; NBA 6/2.292-294: "Hoc enim restat in ista mortali uita libero arbitrio, non ut impleat homo iustitiam cum uoluerit, sed ut se supplici pietate conuertat ad eum cuius dono eam possit implere."; and 1.2.16; NBA 6/2.:326: "Sunt igitur omnes homines quando quidem, ut apostolus ait, in Adam omnes moriuntur, a quo in universum genus humanum origo ducitur offensionis Dei una quaedam massa peccati supplicium debens divinae summaeque iustitiae, quod sive exigatur siue donetur, nulla est iniquitas."

87 Augustine, Conf.3.7.12; NBA 1.68: "Quibus rerum ignarus perturbabar et recedens a veritate ire in eam mihi videbar, quia non noveram malum non esse nisi privationem boni usque ad quod omnino non est." As influences from neo-Platonic way of thinking, Augustine's two works, De ordine and De libero arbitrio are important. See De ord. 1.7.18; NBA 3/1.268: "Nam iste ipse est malorum ordo, ut non diligantur a Deo. An parvus rerum ordo tibi videtur, ut et bona deus diligat et non diligat mala? Ita nec praeter ordinem sunt mala, quae non diligit Deus, et ipsum tamen ordinem diligit; hoc ipsum enim diligit, diligere bona et non diligere mala, quod est magni ordinis et diuinae dispositionis. Qui ordo atque dispositio quia universitatis congruentiam ipsa distinctione custodit, fit, ut mala etiam esse necesse sit. Ita quasi ex antithetis quodam modo, quod nobis etiam in oratione iucundum est, ex contrariis, omnium simul rerum pulchritudo figuratur."

88 Particularly concerning the theory of the soul's pre-existence of Plotinus, G.J.P. O' Daly, "Did St. Augustine Ever Believe in the Soul's Pre-Existence?", AugSt, 5 (1974), pp. 227-235, at p. 231, suggested, "Augustine could speak of pre-existence as a hypothetical possibility", 
cerning evil's understanding of Plotinus, that is, the privation of good, and the notion that evil comes of nothing. ${ }^{89}$ It would be no exaggeration to say that this neo-Platonic notion of the "privation of good" played a decisively important role as a framework for way of thinking for Augustine's construction of the new image of Christian churches. That is, Augustine's anthropology was based on original sin that needed the indispensable grace of God, which was poured in from outside a human being. Therefore, his anthropology needed firm and strong churches as social institutions, which surely intermediated God's grace from outside to Christians.

Contrary to Augustine's neo-Platonic framework, it is fair to say that Julian of Eclanum took the Antiochene realistic view on Jesus Christ, ${ }^{90}$ their imitation theory ${ }^{91}$ and Evagrian understanding of apatheia, that is, the notion of "moderation". ${ }^{92}$ As we already made clear in section 3, part 2 of this article, Julian understood that Jesus Christ had not only complete divine nature but also the same human nature as ours. Therefore, Julian criticized Augustine's assertions that Christ did not have sexual desire, saying that Christ had just the same sexual desire as we did, in order that Christ could become an example regulating sexual desire for us. ${ }^{93}$ This emphasizing of Christ's human nature clearly belongs to the character of the Antiochene tradition. Moreover, Julian often emphasized that sexual desire itself was not an evil at all, but excessive sexual desire could be a sin. This point of view, of excessiveness being sin, was common among Pelagius and Julian and also Evagrius of Ponticus. ${ }^{94}$

and on p. 235, concluded, "it cannot be asserted that the early Augustine ever believed in the human soul's pre-existence."

89 Augustine, De lib. arb. 2.20.54; NBA 3/2.278-280: "Motus ergo ille aversionis, quod fatemur esse peccatum, quoniam defectivus motus est, omnis autem defectus ex nihilo est, vide quo pertineat, et ad Deum non petinere ne dubites. Qui tamen defectus quoniam est voluntarius in nostra est positus potestate. Si enim times illum, oportet ut nolis; si autem nolis, non erit."; and 3.1.1; NBA 3/2.: “... iam si oportunum existimas, cupio per te cognoscere unde ille motus existat, quo ipsa voluntas avertitur a communi atque incommutabili bono et ad propria vel aliena uel infima atque omnia commutabilia conuertitur bona."

90 On the Antiochene tradition in Julian, see Lössl, Julian von Aeclanum, pp. 147-187.

91 Julian's referring to imitation of Adam, see Augustine, Op. imp. 2.47-56; NBA 19/1.240-252.

92 About Pelagius' understanding of apatheia, that is, imperturbabilitas, see N. Yamada, "The Influence of Chromatius and Rufinus of Aquileia on Pelagius - as seen in his Key Ascetic Concepts: exemplum Christi, sapientia and imperturbabilitas," in: Studia Patristica, 70, ed. M. Vinzent, papers presented at the sixteenth International Conference on Patristic Studies, Oxford 2011, Leuven, 2013, pp. 667-670.

93 Augustine, Op. imp. 4.50; NBA 19/2.706-708.

94 Concerning Julian's understanding on "moderation" in the context of "excessiveness", see Augustine, Op. imp. 4.41; NBA 19/2.688; and 5.19; NBA 19/2.898. 
Concerning the purpose of infant baptism, Julian had exactly the same understanding as Pelagius and as John Chrysostom, one of the representatives of the Antiochene tradition. They all believed that the purpose of the liturgy on infant baptism was not to remove original sin but rather to endow infants with various divine spiritual gifts, and ultimately to ensure their transformation into members of the body of Christ..$^{95}$ Significantly, common among Julian, Pelagian and Anthiochene theologians are the strong emphasis on human free will and view of nature that "nature has nothing to do with sin."96 Julian and Pelagius emphasized that there was no sin in nature, and that Christian faith did not depend on natural things. ${ }^{97}$ Pelagians expected not only male but also female Christians to imitate Christ's example by their own free will, because faith did not call nature's differences into question. ${ }^{98}$ Pelagians did not regard human free will as suffering from a deficit like Augustine, rather, they thought that the freedom of will was guaranteed to all human beings. They thought, consistent with freedom of will, that there was equality of all human beings, male or female, slave or free, and just added on to this freedom was the example of Christ given as a gift from God.

When we consider the differences between the two theological frameworks of Augustine and Julian, we should not fail to notice, from this perspective of theological framework, a kind of political bias covered their fierce battle of arguments on human nature, that is, a bias over anti-Manicheism policy. At that time, already in the $380 \mathrm{os}$, the emperor's statement on the prohibition of Manicheism had been promulgated. ${ }^{99}$ Therefore, all clergy were embarrassed to be seen as Manichaean. Julian criticized Augustine's understanding of sexual desire as an evil, saying that it was quite equal to the Manichaean notion of natural evil. Augustine denied it and answered Julian that he (Augustine) took

95 John Chrysostom, In Mt. hom. 28. 3; PG 57.353.

96 Augustine, Op. imp. 3.159; NBA 19/1.580: "Malum igitur naturale esse non potest ac per hoc nec rea ulla naturaliter creatura nec malus auctor. Malum quippe non exstantis invenitur naturae, sed sicut omnis creatura, in quantum conditur, bona est, ita et Deus, naturarum auctor bonarum, nullo operis sui crimine maculates per omnia bonus probatur."

Pelagius, Exp. in ep. Pauli, Rom 4:19; Pelagius's Expositions of Thirteen Epistles of St. Paul, ed. by A. Souter, Cambridge, 1926, p. 40: "Nihil naturae considerat fides, quia omnipotentem nouit esse qui dixit."

98 N. Yamada, "Equality of Men and Women in Free Will: The Narrative Technique of Pelagius' Letters and Pauline Commentaries," in: Men and Women in the Early Christian Centuries, ed. by W. Mayer and I.J. Elmer (Early Christian Studies, 18), Strathfield, NSW, 2014, pp. 251-270.

99 Imperial edicts against Manicheism: in 381, Cod. Theod. 16.10.7 (Mommsen and Krüger, 1/2.899); and in 382, 16.10.9 (Mommsen and Krüger, 1/2.899). 
only natural defect, whose evidence is sexual desire, for an evil, applying the neo-Platonic notion of "privation of good". Nevertheless, the more Augustine defended his understanding of sexual desire as a defect of human nature, it seemed to Julian that Augustine could not be freed completely from Manicheism. ${ }^{100}$ On the contrary, Augustine criticized Julian, if Julian defended human nature including sexual desire as good, that evil or the devil should be considered outside human nature. If Julian asserted the power of Adam's example outside of human nature, then Julian seemed to Augustine to fall into the Manichaean dualism of evil and good. From this perspective, Augustine criticized Julian that Julian had a very Manichaean dualistic view. ${ }^{101}$ Both polemists debated fiercely and decided from the outset that the opponents were Manichaean. We can conclude that these theological debates were also nothing more than political struggles against the political prohibition decreed by the emperor, that is, with the excommunication of Manichaeans in mind. ${ }^{102}$

Contrary to the symbolic characters of Augustine's theology, "deficit" and "helpless", key-concepts expressing the character of Pelagian and Julian's theology and anthropology are "additional" and "voluntary". Writing his Pauline commentaries, Pelagius intended his disciples to awaken their free will and power, which were endowed by God in their human nature. As was introduced in another article, the same-person narrative used in the Pelagius' Pauline commentary played a very effective role in arousing believers' strong voluntary actions to imitate Christ's example. ${ }^{103}$ Julian also emphasized the faultlessness

100 Julian's critique against Augustine as Manichee, see Augustine, Op. imp. 2.202; NBA 19/1.390; 4.19, 23, 29, 51, and 55; NBA 19/2.656-657, 664, 670,708, and 714.

101 Augustine, Con. Iul. 1.8.41; NBA 18.500-502: "Neque enim uno tantum loco, ubi ex Evangelio arborem bonam commemorandam putasti, sed aliis etiam locis disputationis tuae, ista perversitate suffragetus es Manichaeis; sicuti est illud, ubi rursus dixisti: 'Trahi peccatum per naturam non potest, quia per opus Dei opus diaoli transire non sinitur.' ... Vanum est igitur quod dixisti: 'Opus diaboli per opus Dei non transire,' ubi perspicis et manere, Manichaeus autem quantas tibi gratias agat, itane nondum respicis? Nondum expergisceris? Laborat enim Manichaeus, ut ostendat, ex bono Dei opera malum oriri non posse, ut, quod ipse vult, malum nisi ex malo esse non posse credatur.; and Augustine, $\mathrm{Op}$. imp. 3.160; NBA 19/1.580: "Similiter contra te potest ratiocinatio ista contexi; quia non ita fatuus es, ut ingenia fatua id est homines fatuos nasci neges, ergo audi tua fatuitate quantum adiuveris dementiam Manichaei."

102 G.R. Evans, "Neither a Pelagian nor a Manichee," vc, 35 (1981), pp. 232-244, treated the relationship among Julian, Augustine and the Manichees with a measure of the Catholics. Evans is right in referring to the dialectical character of Julian's argument against Augustine, although Evans's comparison was somewhat schematic and he did not consider the sexual and political matters of $\mathrm{Op}$. imp.

103 Yamada, "Equality of Men and Women," pp. 268-270. 
of human free will, as he wanted believers to become independent by the reciprocal working between Christ's example and the power of human free will, and doing so, ${ }^{104}$ Julian was thinking that independent Christians could fight against diabolical power outside human nature, and endure social injustice outside churches. The Pelagians' image of church, which consisted of such independent Christians, was undoubtedly the traditional, older type of church, that is, believers' communities as social minorities, which were common in the age of Christian persecutions. For such independent believer communities, strong authorities and firm institutions, which could mediate God's grace, including forgiveness of sin and removal of original sin objectively from outside, were not always necessary. On the other hand, for Christians who were recognizing a "deficit" in their human nature and who were feeling "helpless" in their free will, such institutionally strong churches were absolutely necessary.

\section{Ecclesiastical Circumstances and Political Diplomacy surrounding Pelagians and the Church of Rome}

If we focus on the circumstances of the church of Rome at that time, we can recognize a difficult political and ecclesiastical situation which surrounded the church of Rome. ${ }^{105}$ The new type of church, which could function as a strong institution for objectively mediating God's grace and give answer to the requirement of compulsory infant baptism, seemed to be necessary for converting many pagans in the city of Rome. ${ }^{106}$ It goes without saying that Augustine's type of church was the very church that was required in the western world. Finally, concerning the ecclesiastical situation at the end of the Roman empire, we would like to investigate Augustine's diplomacy and the social conditions of the Roman church for excommunication of the Pelagians.

104 For Julian's understanding of exemplum Christi and his imitation theory, see Augustine, Op. imp. 2.47; NBA 19/1.240-242; and 4.54 and 57; NBA 19/2.712 and 716-718.

105 O. Wermelinger, Rom und Pelagius. Die theologische Position der römischen Bischöfe im pelagianishcen Streit in den Jahren 411-432 (Päpste und Papsttum, 7), Stuttgart, 1975, pp. 134282.

106 E. Ferguson, Baptism in the Early Church: History, Theology, and Liturgy in the First Five Centuries, Grand Rapids, Mich-Cambridge, 2009, pp. 756-769. Concerning infant baptism at the end of fourth century, p. 760 : "Since Siricius is addressing exceptions to the preferred times for baptism, especially in cases of emergency baptism (which already had two centuries of precedent), conclusions about the general practice of infant baptism are dubious." 


\subsection{Ecclesiastical and Political Diplomacy of Augustine}

From the end of the fourth century to the beginning of the fifth century, in the circle of the eastern churches, it was not the theory of original sin but another christological issue that was topical, viz., Nestorianism. It was well known that Cyril of Alexandria strongly criticized Nestorius, bishop of Constantinople, and Cyril tried using all means to excommunicate Nestorians. ${ }^{107}$ Cyril tried to draw the attention of the bishop of Rome to the Nestorian issue in the eastern churches. ${ }^{108}$ On the other hand, from one of the newly discovered Divjack letters, it is obvious that Augustine tried to attract the attention of Cyril concerning the Pelagian heresy in the western world. ${ }^{109}$ At the same time, the bishop of Rome and the western churches confronted a kind of crisis of division caused by the strong appeal of African bishops, who accused Pelagians of heresy.

Concerning Cyril's intention over this anti-Pelagian judgement, G. Bonner concluded that the conventional view of scholars was that Cyril took an active interest in Pelagianism only in relation to his anti-Nestorianism, and was challenged by Epistula $4^{*}$ of the Divjack letters. ${ }^{110}$ G.D. Dunn stated the conventional idea "that Cyril was motivated to deal with the Pelagians at Ephesus because Caelestius and Julian of Eclanum had taken refuge in Constantinople with Nestorius- still is the most likely explanation." However, Dunn wishes to demonstrate that both before and after Cyril's exposure to Augustine's Pelagian concerns Cyril had written about questions of grace and the hereditary nature of sin and free will in ways that were opposed to the notions expressed by Pelagius. ${ }^{111}$ Investigating Cyril's theological familiarity on the notions of sin of Adam and Eve and ongoing effect on all human kind to Augustine's doctrine of original sin (Cyril did not use the term "original sin"), Dunn formed the conclusion, "even though Cyril may not have moved politically against Pelagius until the council of Ephesus in 431, he was, from early in his episcopate, theologically an opponent of Pelagius's views implicitly though not explicitly."112 Nevertheless, if we take Beatrice's analysis of supporters and opponents of he-

\footnotetext{
107 J.A. McGuckin, Saint Cyril of Alexandria and the Christological Controversy: Its History, Theology, and Texts, Crestwood, NY, 2004, pp. 1-125.

108 McGuckin, Saint Cyril of Alexandria, pp. 34-53.

109 Augustine, Ep. $4^{*}$; NBA 23/A.42-46.

110 G. Bonner, "Some Remarks on Letters 4* and 6*." in: Les lettres de saint Augustine découvertes par Johannes Divjak: Communications présentées au colloque des 20 et 21 Septembre 1982 (CEASA, 98), Paris, 1983, pp. 155-164.

111 G.D. Dunn, "Augustine, Cyril of Alexandria, and the Pelagian Controversy." AugSt, 37 (2006) pp. 63-88, at p. 79.

112 Dunn, "Augustine, Cyril of Alexandria," p. 87.
} 
reditary sin, and the different frameworks of neo-Platonic (Alexandrian) and Antiochene theologies, and also an ideology-critical hermeneutic into consideration, the conventional views (of emphasizing only superficial, political intentions of Cyril) and the other interpretations (of stressing a more essential, theological relationship between Cyril and Augustine) do not contradict each other at all. Cyril belonged to the supporters of hereditary sin, to neo-Platonic (Alexandrian) scholars, and in addition took politically tactical actions not only against the Nestorians but also against the Pelagians.

In addition to the above-mentioned severe debate concerning christology between Cyril and Nestorius, since the end of the fourth Century, the bishop of Rome had already been exposed to another serious ecclesiastical issue, that is, the order of the major sees. ${ }^{13}$ The Council of Constantinople, held in 381, accepted a proposal from the see of Constantinople to rank New Rome second after Old Rome in the existing order of the major sees. ${ }^{114}$ Such a movement to wedge the see of Constantinople into the second rank among the traditional order of major sees (first Rome, second Alexandria, third Antioch, fourth Jerusalem, and fifth Ephesus), aiming at the essential first rank among the eastern bishoprics, was still influential at the beginning of the fifth century. Rome's position as the highest rank was threatened to be devalued by Constantinople's squeezing into the order. The see of Alexandria was also exposed to the threat of demotion, and the see of Ephesus was also under the threat of being deprived of the position as one of the major sees because Ephesus was located geographically very near Constantinople. The sees of Rome, Alexandria, and Ephesus had to link up with each other to resist the power of the see of Constantinople and its imperial support. ${ }^{115}$ The bishop of Rome inevitably needed to ally with the bishops of Alexandria and Ephesus.

If we consider the power balance among those bishoprics, it is obvious that the situation of the bishop of Rome was quite unstable. The bishop of Rome had to unite the western bishops and to maintain close cooperation with the bishop of Alexandria. In such an ecclesiastically tense atmosphere, Zosimus, bishop of Rome, was strongly pressured to excommunicate Pelagians by the

113 W.H.C. Frend, The Rise of Christianity, London, 1984, pp. 741-773.

114 V. Limberis, "The Council of Ephesos - The Demise of the See of Ephesos and the Rise of the Cult of the Theotokos," in: Ephesos Metropolis of Asia: An Interdisciplinary Approach to its Archaeology, Religion, and Culture, ed. by H. Koester, Cambridge, Mass., 1995, pp. 332333. See council of Constantinople, can. 3; Conciliorum Oecumenicorum Generaliumque Decreta, vol. 1: The Oecumenical Councils from Nicaea I to Nicaea II (325-787), ed. by G. Alberigo (Corpus Christianorum Conciliorum Oecumenicorum Generaliumque Decreta, 1), Turnhout, 2006, p. 66.

115 McGuckin, Saint Cyril of Alexandria, pp. 53-125. 
African bishops in 418. ${ }^{116}$ In that very year, Emperor Honorius was informed of an attack on a retired Roman officer by Pelagians. ${ }^{117}$ The emperor promulgated an imperial letter to the praetorian prefect of Italy, Palladius, to exile Pelagians from the city of Rome. ${ }^{118}$ On such a serious occasion after the promulgation of the emperor, as if by mutual prior consent, on the very next day Zosimus, the bishop of Rome, endorsed the excommunication of Pelagians at the local synod of Carthage in his now lost Tractoria. ${ }^{119}$ After the fierce controversy with Augustine, Julian left for the East to Nestorius of Constantinople. Unfortunately, Julian was excommunicated with the Nestorians by Cyril of Alexandria at the synod of Ephesus in 431. ${ }^{120}$ Moreover, as it is well known in church history, Cyril's supporters decided the excommunication of Nestorians by taking tactical measures before the arrival of the Nestorian supporters in Ephesus. It was obvious that the excommunication of Julian was done so that Cyril's side could gain attention and develop better cooperation with the western bishops, in order to complete the excommunication of the theologians, who emphasized the humanity of Christ and denied the idea of hereditary sin combined with sexual desire. ${ }^{121}$

It is at least possible for us to say now that the Pelagians, particularly Julian, were not only the losers of the theological controversy between different authentic parties but also of the church-political sacrifices in the struggle for supremacy. Moreover, the Pelagians were the sacrifice of the institutionalization of the Roman church and their idea of independent voluntary Christianity. In this sense, all of Augustine's and Julian's theological and anthropological statements should be investigated also from ecclesiastical and political perspectives. In doing so, we can evaluate and correctly judge the following Julian's fierce critique against Augustine, which was against Augustine's "actual political" deeds referred only here in Opus imperfectum, and which deeds Augustine denied. Julian criticized Augustine as follows:

116 Wermelinger, Rom und Pelagius, pp. 146-165.

117 Wermelinger, Rom und Pelagius, p. 206.

118 Honorius, Ep. ad Palladium (Ad conturbandum) = Collectio Quesnelliana, Ep. 14; PL 48.379386. See M. Marcos, "Anti-Pelagian Legislation in Context," in: Lex et religio, XL Incontro di Studiosi dell'Antichità Cristiana, Roma, 10-12 maggio 2012 (SEAug, 135), Rome, 2013, pp. 317-344.

119 See Augustine, Con. duas. ep. Pel. 2.3.5; NBA 18.240-244.

120 Condemnation of Pelagianism: Gesta Ephesena; Aco, t. 1: Concilium Universale Ephesinum, vol. I: Acta graeca, pars 3: Collectio Vaticana 81-119, ed. by E. Schwartz, Berlin-Leipzig, 1927, pp. 27-28.

121 Wermelinger, Rom und Pelagius, pp. 232-237; and McGuckin, Saint Cyril of Alexandria, pp. 35-125. 
Why have you hired people and stirred up rebellions at Rome? Why have you fattened herds of horses throughout almost the whole of Africa at the expense of the poor and sent them under the care of Alypius to tribunes and centurions? Why have you bribed the powers of the world with gifts from the inheritances of matrons so that the straw of public fury might be set blaze against us? Why have you dispelled the quiet of the churches? Why have you stained the days of a religious emperor with the impiety of persecutions if we say nothing other than what you too are forced to admit is good?122

We cannot be sure any more if Julian's critiques were true or if Augustine's denial was true. Nevertheless, considering that Augustine justified requiring intervention of Imperial militaries on the oppositions of the Donatists in 408 to $421,{ }^{123}$ it seems undeniable that Augustine called on the imperial high administration to persecute Pelagians. Because Augustine suggested military intervention for taking back "robbed sheep" not only in the case of "deprived sheep by force", but also in the case of "tempted sheep by honeyed words", ${ }^{24}$ it seems

Augustine, Op. imp. 3.35; NBA 19/1.466: "Cur ergo, si creditis et hoc bonum esse quod dicimus, et illud bonum esse quod dicitis, tantis totam Italiam factionibus commovistis? Cur seditiones Romae conductis populis excitastis? Cur de sumptibus pauperum saginastis per totam pene Africam equorum greges, quos prosequente Alypio tribunis et centurionibus destinastis? Cur matronarum oblatis hereditatibus potestates saeculi corrupistis, ut in nos stipula publici furoris arderet? Cur dissipastis ecclesiarum quietem? Cur religiosi principis tempora persecutionum impietate maculastis, si a nobis nihil aliud dicitur, quam quod etiam tu bonum cogeris confiteri?"

Augustine, Ep. 93; NBA 21/2.806-876, stated the possibility of military intervention against the Donatists already in the letter to Vincentius in 408. In Ep. 185; NBA 23.10-74 to the African tribune Boniface in 417 also, Augustine admitted armed intervention against illegal actions of the Donatists. See G.D. Dunn, "Discipline, Coercion, and Correction: Augustine against the Violence of the Donatists in Epistula 185," Scr., 13 (2017), pp. 114-130.

124 Augustinus, Ep. 185.6.23; NBA 23.40-42: "Cur ergo non cogeret ecclesia perditos filios, ut redirent, si perditi filii coegerumt alios, ut perirent? Quamvis etiam illos, quos non coegerunt, sed tantummodo seduxerunt, si per terribiles sed salubres leges in eius gremium reuocentur, blandius pia mater amplectitur et de illis multo amplius quam de his, quos numquam perdiderat, gratulatur. Annon pertinet ad diligentiam pastoralem etiam illas oves, quae non violenter ereptae sed blande leniterque seductae a grege aberraverint et ab alienis coeperint possideri, inventas ad ovile dominicum, si resistere voluerint, flagellorum terroribus vel etiam doloribus revocare: paresertim quoniam, si apud fugitivos et praedones servos fecunditate multiplicentur, plus habet iuris, quod in eis dominicus character agnoscitur, qui in eis, quos suscipimus nec tamen rebaptizamus, minime violatur?" 
to be possible that Augustine used some compelling force in order to expel "the Pelagian heresies", just as he did against the Donatist schismatics. ${ }^{125}$ At the very least, it is quite obvious that we should always take into account the political intentions behind theological affirmations of both clerics, Augustine and Julian, and their rhetorical perspectives.

\subsection{Social Conditions Surrounding Roman Church for Choosing Augustine's Doctrine of Original Sin}

Since the era of Augustus, imperial encouragement of marriage and fecundity was a matter of course, and ordinary people also responded to this encouragement. The role of Roman women was to bear children and to bring them up as successors in their families. Even after the beginning of the Christianizing of Christian emperors, according to the study of G. Nathan and A. Arjava, the secular tendency for marriage and fecundity even in the Roman Churches did not change at all. ${ }^{126}$ Therefore, although Pelagius and Jerome tried to introduce the eastern type of asceticism into Roman society, they could not help but fail. ${ }^{127}$

At the same time, the increasing imposition of celibacy on western Roman clerics and the intensification of the authority of bishop of Rome developed rapidly. We can be certain of the patriarchal tendency of the western churches at that time due to the strong sexism of Ambrosiaster, a senior Roman priest. ${ }^{128}$

125 Augustine, Ep. 185.7.28; NBA 23.50:"Ubi satis ostendit, quid facere postea deberent Christi dispensatores, quando imperatores Christianos priclitante ecclesia reperirent. Hinc ergo factum est, ut imperator religiosus et pius perlatis in notitiam suam talibus causis mallet piissimis legibus illius impietatis errorem omnino corrigere et eos, qui contra Christum Christi signa portarent, ad unitatem catholicam terrendo et cohercendo redigere quam saeviendi tantum modo auferre licentiam et errand ac perevndi relinquere."

126 G. Nathan, The Family in Late Antiquity: The Rise of Christianity and the Endurance of Tradition, London-New York, 2000, pp. 115-128; and A. Arjava, Women and Law in Late Antiquity, Oxford, 1998, pp. 77-84. Also see for the social view in more macro level, R. MacMullen, Christianizing the Roman Empire (A.D. 100-40o), New Haven-London, 1984; and R. MacMullen, Corruption and the Decline of Rome, New Haven-London, 1988.

127 Jerome, Ep. 22.34-36; CSEL 54.196-201; J.N.D. Kelly, Jerome, His Life, Writings, and Controversies, London, 1975, pp. 195-209; P. Brown, Religion and Society in the Age of St. Augustine, New York, 1972, pp. 208-218; and E.A. Clark, The Origenist Controversy: The Cultural Construction of an Early Christian Debate, Princeton, 1992, pp. 20-42, 121-151, and 159-193.

128 D.G. Hunter, "The Paradise of Patriarchy: Ambrosiaster on Woman as (Not) God's Image", JTS n.s., 43 (1992), pp. 447-469; Ambrosiaster, Questiones 21; CSEL 50.48; 45.3; CSEL 50.83; and 106.17; CSEL 50.243. Hunter, "The Paradise of Patriarchy," p. 448, interpreted Ambrosiaster's misogynistic remarks as part of the patriarchal trend at that time: "Ambrosiaster's discomfort with asceticism and with ascetically oriented exegesis was rooted in a desire both to maintain ancient Roman tradition and to protect the prerogatives of the clergy. As 
The ascetic way of independent Christian life based on free will and its working for making every moment of life one's own, which Pelagius and Julian wished especially for Roman women, was too early for almost all of the Roman masses to accept and too radical for Church authorities.

Finally, particularly in the western part of the Roman empire, the majority of upper class Roman society still remained Pagans and did not want to convert to Christianity. We can read in Augustine's De civitate Dei that there were strong voices at that time which attributed the decline of Roman Empire to Christianity. ${ }^{129}$ Against the pagan powers in the western side of Roman empire, the western churches were searching for an effective scheme to Christianize Roman society, more concretely arguing the theologically effective reasoning for making infant baptism obligatory. To make infant baptism compulsory, Pelagian's reasoning seemed to the church authorities to be very feeble. Rather, Augustine's doctrine of original sin, namely the idea adopted from the tradition of hereditary sin-without infant baptism to remove original sin inherited by even new born babies, they cannot enter heaven-was decisively effective for arguing for this perspective. In the end, combined with ecclesiastical and political reasons above mentioned and as a result of being forced to be strongly institutionalized, the western churches chose not Pelagian's but Augustine's theological rhetoric.

\section{Conclusion}

Augustine's neo-Platonic philosophical framework and negative evaluation of human sexual desire were his logical methodology and its result in order to justify the helplessness of human nature and the theory of original sin. On the other hand, Julian's imitation theory between the example of Christ and imago Dei of Christians and Julian's affirmative view on sexual desire were his methodology and its result so as to justify his theological core statements of the goodness of human nature and additionally given divine graces. As Beatrice made clear, Augustine's victory in the Pelagian controversy means the victory of the supporters of hereditary sin. It is apparent that Augustine could offer the most persuasive argument for legitimating the necessity of infant baptism.

such, his views represent a significant departure from previous Christian tradition, as well as a response to what he perceived as the disruptive effects of the ascetic movement." Cf., his most recent article, "Augustine on the Body", in: The Blackwell Companion to Augustine, ed. by M. Vessey, Oxford, 2012, pp. 396-407.

Augustine, De civ. Dei 1.10; NBA 5/1.36-40. 
Pelagian's argument for reasoning infant baptism was clearly feeble and weak. This is the first, direct reason for Augustine's victory.

Both Augustine and Julian used rhetorical devices, which Grillmeier adopted for investigating the excommunication of Nestorians, in order to condemn the opponent's theological statements. Nevertheless, Augustine vastly surpassed Pelagians in tactics and his abilities in using rhetorical devices. Although the quoted biblical and patristic sentences and texts were incorrect evidence, Augustine consistently used rhetorical devices effectively. Moreover, both rhetorical affirmations were regulated by political power biases, which were caused by imperial promulgations for excommunicating Manichaeism and paganism. Also in the political and church-political tactics, Augustine exceeded Julian and Augustine worked actively for his Roman superiors and the bishop of Alexandria, which resulted in the successful excommunication of the Pelagians.

Julian's absolutely positive evaluation of human nature, particularly human sexual desire, formulated an emphasis on human will and nature. Julian understood that human will could respond to divine will and various graces, which were given diversely and in additional to human nature; that is, that human will was also an originally fundamental grace in and of itself. In Julian's view, there was no discrimination between man and woman, Christians and pagans in such affirmative evaluations on human will and nature. This character of equality and of spontaneous independence of the Christians is nothing more than the same image of that of early church traditions during the era of persecutions.

On the contrary, Augustine's theory of original sin, which was constructed by the understanding of a "deficit" of human nature, needed a strong authoritative ecclesiastical institution, which functioned to intermediate so as to pour divine grace into "helpless" Christians. Augustine's understanding of special divine grace to heal the natural "deficit" brought distinctive discrimination between Christians and pagans. In the end, the Roman church, which faced many challenges politically and ecclesiastically at that time, chose Augustine's theory of original sin and his rhetoric as theoretical bases of infant baptism, and finally excommunicated Pelagians as heretics.

In fact, to clarify the true reasons and meaning of Augustine's victory and the Pelagians' defeat is as difficult to do as explicating the true reason and meaning of Christ's death by crucifixion. Nevertheless, I have tried to sum up the reasons why Augustine won and the Pelagians lost the controversy in this present paper. This paper is exploratory and still insufficient for accomplishing our main purpose, but I hope it can contribute to the development of a more complete, holistic approach to the authenticity of the Pelagians. 